Nat. Hazards Earth Syst. Sci., 18, 1985-1998, 2018

https://doi.org/10.5194/nhess-18-1985-2018

(C) Author(s) 2018. This work is distributed under

the Creative Commons Attribution 4.0 License.

\title{
Tsunamis boulders on the rocky shores of Minorca (Balearic Islands)
}

\author{
Francesc Xavier Roig-Munar ${ }^{1}$, Joan Manuel Vilaplana ${ }^{2}$, Antoni Rodríguez-Perea ${ }^{3}$, José Ángel Martín-Prieto ${ }^{1}$, and \\ Bernadí Gelabert ${ }^{4}$ \\ ${ }^{1}$ QU4TRE, environmental consulting, Carritxaret 18.6, es Migjorn Gran, 07749 Minorca, Spain \\ ${ }^{2}$ Department of Earth and Ocean Dynamics, RISKNAT Group, Geomodels, Universitat de Barcelona, \\ Martí i Franquès, s/n 08028 Barcelona \\ ${ }^{3}$ Department of Geography, Universitat de les Illes Balears, Carretera de Valldemossa, km 7.5, 07122, Palma, Majorca, Spain \\ ${ }^{4}$ Department of Biology, Universitat de les Illes Balears, Carretera de Valldemossa, km 7.5, 07122, Palma, Majorca, Spain
}

Correspondence: Bernadí Gelabert (bernadi.gelabert@uib.es)

Received: 29 August 2017 - Discussion started: 12 September 2017

Revised: 6 June 2018 - Accepted: 13 June 2018 - Published: 17 July 2018

\begin{abstract}
Large boulders have been found on marine cliffs of 24 study areas on Minorca, in the Balearic archipelago. These large imbricated boulders of up to $229 \mathrm{t}$ are located on platforms that comprise the rocky coastline of Minorca, several tens of meters from the edge of the cliff, up to $15 \mathrm{~m}$ above the sea level and kilometers away from any inland escarpment. They are mostly located on the south-eastern coast of the island, and numerical models have identified this coastline as a zone with a high probability of tsunami impact. The age of the boulders of the studied localities range between $1574 \mathrm{AD}$ and recent times, although most of them are concentrated around the year $1790 \mathrm{AD}$. Although some storm waves might play a role in their dislodging, the distribution of the boulder sites along the Balearic Islands, the degree and direction of imbrication and the run-up necessary for their placement suggest transport from northern African tsunami waves that hit the coastline of Minorca.
\end{abstract}

\section{Introduction}

Although they are less frequent than those of the Pacific and Indian oceans, tsunamis in the Mediterranean Sea are well known from historical accounts (Soloviev, 1990). Large boulder accumulations observed and studied on various coastlines of the western Mediterranean have been associated with extreme wave events (tsunamis or storms): France (Shah-Hosseini et al., 2013), southern Italy (Barbano et al.,
2010, 2011; Mastronuzzi et al., 2007; Mastronuzzi and Pignatelli, 2012; Pignatelli et al., 2009; Scicchitano et al., 2007, 2012) and Algeria (Maouche et al., 2009). Large boulders placed over coastal rocky cliffs on Minorca island have been found mainly on the south-eastern and western coastline (Roig-Munar, 2016) (Fig. 1). Some are positioned well above the maximum stand of any recorded storm wave (up to $27 \mathrm{~m}$ ), many show imbricated boulder ridges, and all of them are located far from any high inland relief that might explain an origin from gravitational fall.

The presence of large boulders on the rocky shores of the Balearic Islands has been analyzed by Bartel and Kelletat (2003), Schefers and Kelletat (2003) and Kelletat et al. (2005), but only on the island of Majorca. The authors linked the presence of large boulders on the coastal platform of Majorca with storm waves and/or tsunami processes, establishing a simple equation (transport figure) to discern those displaced by a storm wave or a tsunami event. In fact, in many areas of the western Mediterranean, imbricated, metric size boulders have been interpreted as remnants of the tsunamis that occurred in the last centuries (Pignatelli et al., 2009). Only on the Atlantic coast, which has much higher fetch, storm wave period and tidal range, are imbricated boulders at high altitudes tied to storm processes (Hansom and Hall, 2009; Etienne and Paris, 2010; Hall, 2011). However, the distinction between tsunami or storm boulders is not easy nor without controversy, though it is based on a set of sedimentological, morphological and chronological criteria to be 

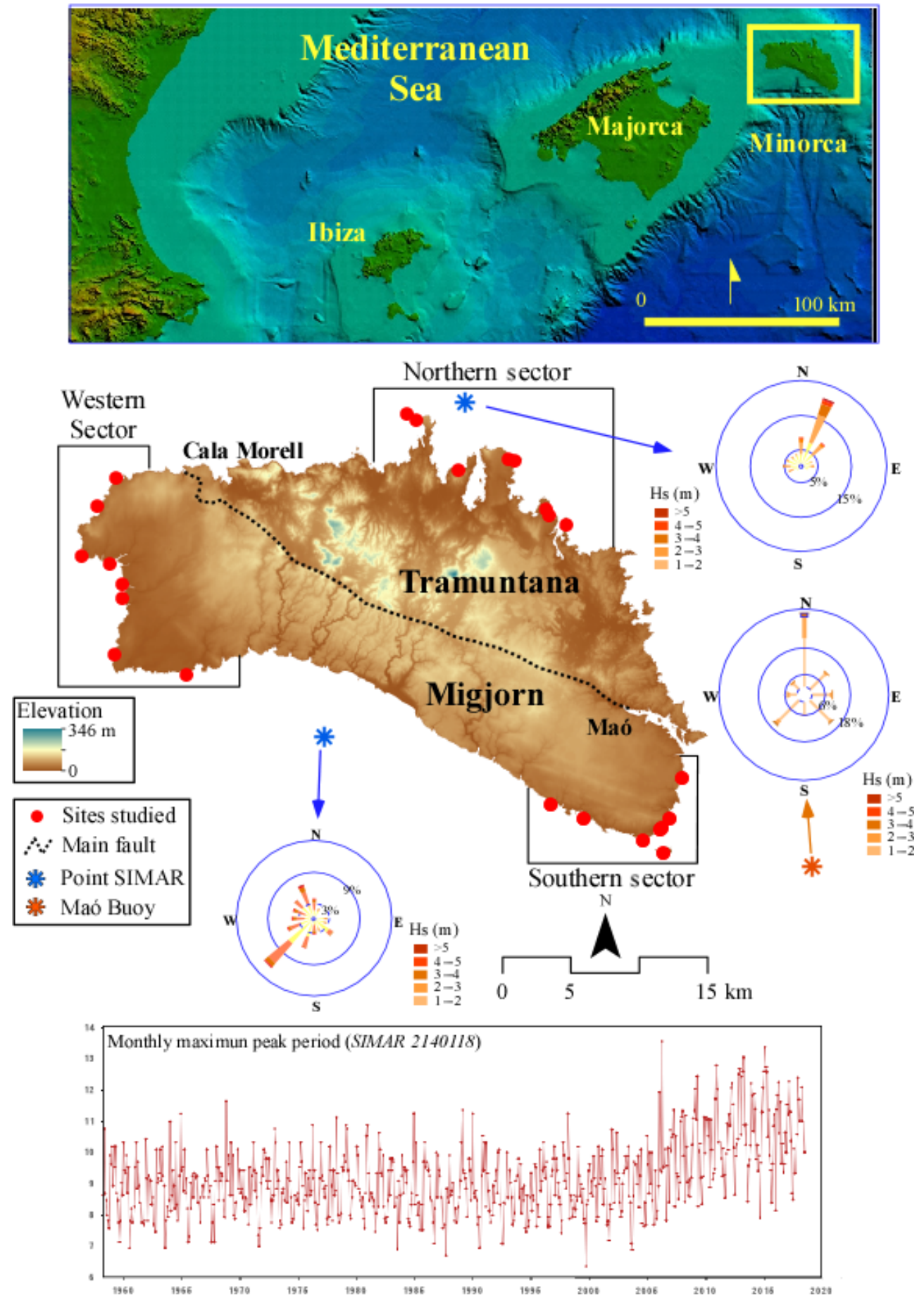

Figure 1. Boulder sites at the Balearic Islands (top). Location of the sampled areas (middle): (a) west, (b) north and (c) south-east Minorca and some rose diagrams of waves (orange) and wind regime (blue). Monthly maximum wave period (in seconds) is representative of the Minorca wave regime (bottom).

treated in each case (Scheffers and Kinis, 2014). The main goal of this article is to demonstrate that some of the boulders located close to the coastal cliffs of Minorca were transported and deposited by tsunamis that occurred in the recent past and mostly originated from submarine earthquakes on the Algerian coast. 


\section{Study site}

\subsection{Geology of the study areas}

Both from a geological and geomorphological point of view, Minorca is divided into two parts by an imaginary WNWESE line that extends from Maó to Cala Morell (Fig. 1): (a) the Migjorn, which covers the southern half of Minorca, is formed by undeformed calcareous materials from the upper Miocene forming a nearly horizontal platform; and (b) the Tramuntana includes all the outcrops of Palaeozoic, Mesozoic and Oligocene age. These materials are faulted and folded by the alpine orogeny and constitute the northern half of the island is characterized by gentle hills and valleys.

The eight study sites of the southern sector (Fig. 1) and the eight study sites of the western sector are located on carbonated, horizontal, well-developed bedding, with Upper Miocene rocks forming a marine cliff with heights between 4.5 and $20 \mathrm{~m}$. Five of the eight study sites of the northern sector correspond to outcrops of massive Jurassic limestones, forming sea cliffs between 2 and $20 \mathrm{~m}$ height. The other three study sites of the northern area are located on PlioQuaternary eolianites: the Tirant and Tusqueta sites constitute a gentle ramp where cliffs are absent, while in Punta Grossa, eolianites comprise an $8 \mathrm{~m}$ high coastal cliff.

\subsection{Maritime climate}

The Mediterranean basin is characterized by a highly indented coastline that creates some small and well-defined subbasins, where wave energy is conditioned by wind speed and by limited fetches (Lionello et al., 2006). In the western Mediterranean, the most intense waves come from the NE (Sotillo et al., 2005), although the NW also generates strong waves between the Balearics, Corsica and Sardinia (Bertotti and Cavaleri, 2008).

The coast of Minorca island is subject to a maritime climate characterized in the last 50 years by a maximum wave height of $10 \mathrm{~m}$ from a NNE-dominant direction (Cañellas, 2010) (Fig. 1). The eastern coast of the island is characterized by a maximum wave height of $8.5 \mathrm{~m}$ with a dominant $\mathrm{N}$ component (Cañellas, 2010). At the northern sector of the island, the maximum wave height recorded since 1958 was $11 \mathrm{~m}$ height from a NNE direction. The Hs50 is estimated at $9.88 \mathrm{~m}$ (Cañellas, 2010). Monthly maximum periods calculated for WANA points around Minorca are between 11 and $14 \mathrm{~s}$ (Fig. 1). The tidal regime in Minorca is of very low amplitude $(30 \mathrm{~cm})$, almost negligible for this study.

Mediterranean hurricanes, called medicanes in the Mediterranean, are generated by intense tropical cyclones and may cause a more likely extreme waveform on the coast of Minorca. The remarkable medicane of 10-11 November 2001 was associated with the seventh most intense cyclone around the Mediterranean, in the period ERA-40 (1957-2002) and is the most intense of all detected medi-

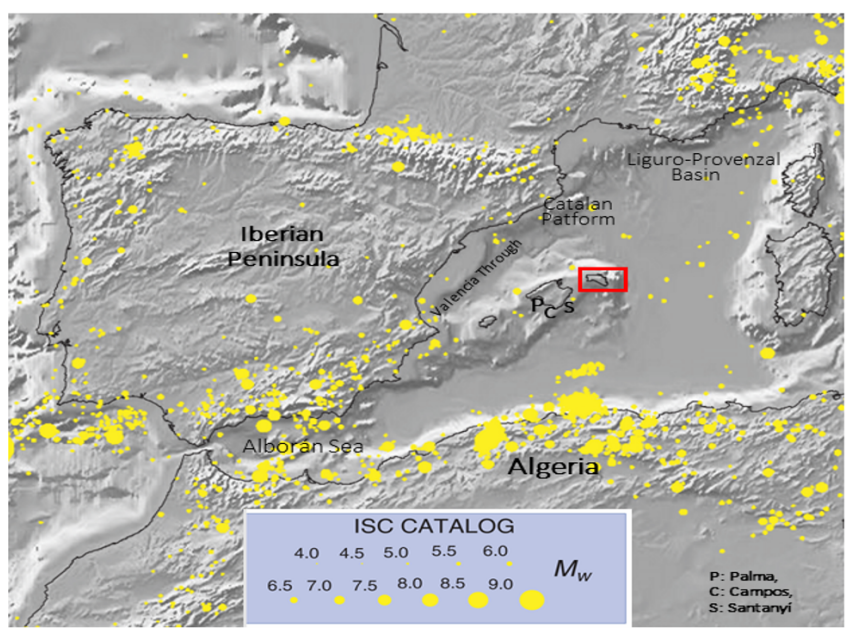

Figure 2. Instrumental seismicity of the western Mediterranean region (from ISC-GEM Global Instrumental Earthquake Catalogue) for depth interval 0-50 km. Modified from Vanucci et al. (2004). P refers to Palma, $\mathrm{C}$ refers to Campos and $\mathrm{S}$ refers to Santanyi.

cane in the westernmost Mediterranean, near the Balearic Islands (Genovés et al., 2006). The wind exceeded $150 \mathrm{~km} \mathrm{~h}^{-1}$, affecting a large marine extension and causing waves up to $11 \mathrm{~m}$ of significant height (Jansà, 2013). The number of intense cyclones affecting the Balearic Islands during the period 1957-2007 is between 5 and 10 (Homar et al., 2006).

According to Papadopoulos (2009), the major tsunamigenic source in the western Mediterranean is located north of Algeria (Fig. 2). The last tsunami registered was in 2003 and resulted in a large amount of damage to several marinas and entrances of the Balearic Islands, mostly due to harbor resonance (Vela et al., 2014). Roger and Hébert (2008) made a numerical simulation of this tsunami affecting the Balearic Islands (Fig. 3). Several seismic tsunamis have been recorded in the Balearic Islands; some of them have been described in chronicles as Fontseré (1918) (Table 1).

\section{Methodology}

In this study, 3.144 boulders located in 24 areas of Minorca island (Fig. 1) have been analyzed. Boulder size was measured, as well as height above sea level, and the distance from the edge of the cliff. Orientation and imbrication were also considered, together with their geomorphological context (Fig. 4). The transport figure (TF; Scheffers and Kelletat, 2003) was used to assess the power needed to dislodge and transport each boulder. TF is calculated as the product of the height above sea level, distance from the edge of the cliff and weight. Scheffers and Kelletat (2003) consider boulders with $\mathrm{TF}>250$ to be indicative of tsunami boulders. In this paper we focus our study on boulders with TF $>1000$ and on boulders found on cliffs well above the maximum storm wave height recorded in Minorca, which is $11 \mathrm{~m}$ (Cañellas, 2010). 

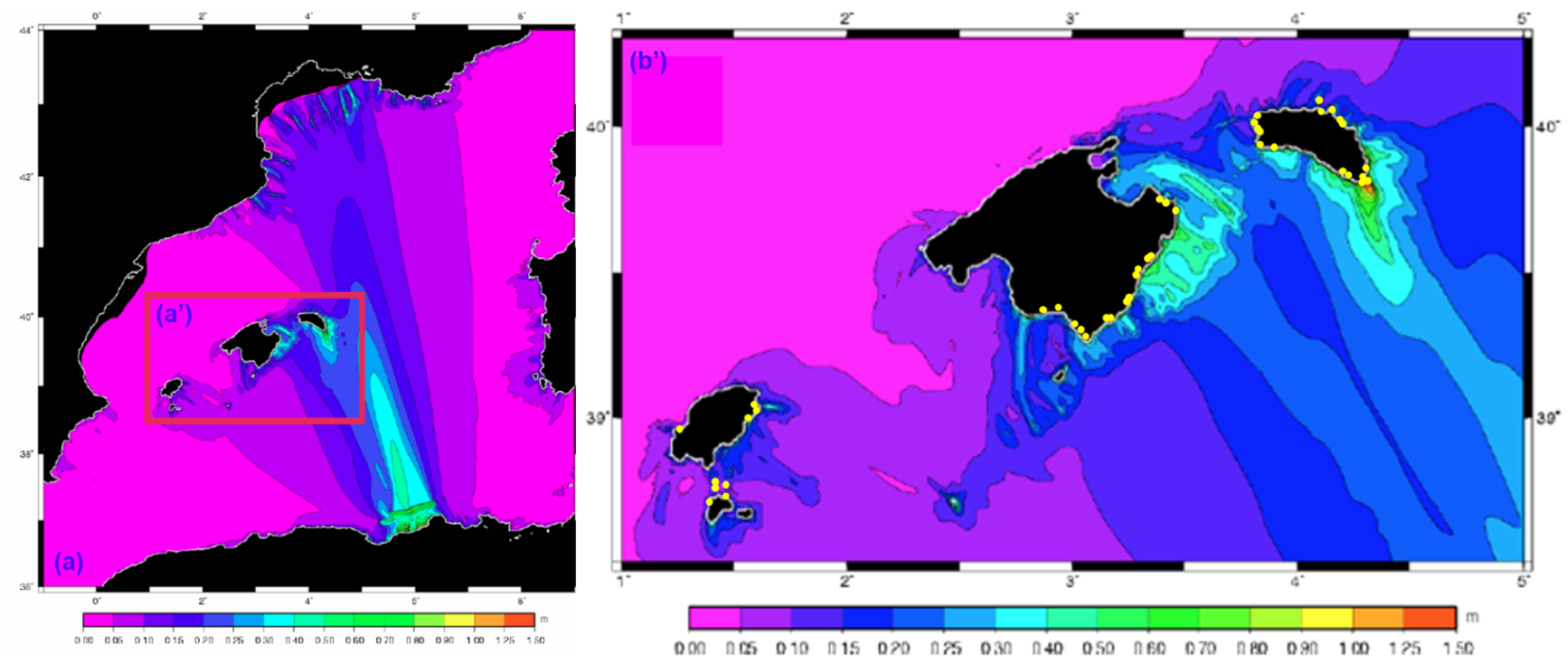

Figure 3. Tsunami simulation, generated from a northern Algeria earthquake, impacting the Balearic Islands. Accumulated maximum height $1.5 \mathrm{~h}$ after the break of the fault, three segments at a time, with a deviation of $80^{\circ}$. Source: Roger and Hébert (2008). Yellow dots correspond to study sites where boulders have been found. Note the correspondence between the simulation results and the location of the boulders.

Table 1. Historical tsunami phenomena impacting the Balearic Islands, modified from Roig-Munar (2016). Information sources (IS): (1) Fontseré (1918), (2) Martinez-Solares (2001) and Silva and Rodríguez Pascua (2014) (see Fig. 2, for location).

\begin{tabular}{lllc}
\hline Data & Affected area & Phenomenon & IS \\
\hline 1660 & Majorca, Palma, Campos & Earthquake and tsunami & 1 \\
1721 & Balearic Islands & Earthquake and seawater withdrawal & 1 \\
1756 & Majorca, Santanyí & Tsunami and big waves & 1 \\
1756 & Balearic Islands & Tsunami and flooded coasts & 2 \\
1790 & Alboran Sea & Tsunami & 2 \\
1804 & Alboran Sea & Tsunami & 2 \\
1856 & Minorca, Maó & Tsunami and seismic wave & 1 \\
1856 & Algeria & Tsunami & 2 \\
1885 & Algeria & Sea level changes & 2 \\
1891 & Algeria & Tsunami & 2 \\
1918 & Minorca, Maó & Seismic wave & 1 \\
2003 & Algeria & Earthquake (7.0) and tsunami & 2 \\
\hline
\end{tabular}

Calculation of boulder weights requires a good estimation of density and volume (Engel and May, 2012). In most cases the product of the three axis - $a$ (length), $b$ (width) and $c$ (height) - of each boulder exceeds the true volume of the boulder. Sampling comparisons have been made between Vabc, and a more precise measurement obtained by triangulating the boulder in homogeneous parallelepipeds (Fig. 5a). This procedure produced a correction coefficient of 0.62 that has been applied to all boulders analyzed in this study. Densities of each lithology were calculated using the Archimedean principle of buoyancy in seawater.

In addition to TF, different equations (Table 2) have been applied to all the localities to calculate the water height required to dislodge and/or move each boulder. Nott (2003) has pre-defined settings for transported boulders (submerged, subaerial and joint-bounded boulders JBB), and for each boulder type, a different equation for both tsunami and storm waves. Most Minorcan boulders were dislodged from cliff edges (Fig. 6), so joint-bounded and subaerial scenarios must be considered. Only nine boulders show features (marine fauna or notch fragments) indicating that they were originally submerged. Pignatelli (2009) defined a new equation to obtain the minimum tsunami height (HT) that can move a joint-bounded boulder (JBB). The Nott-derived equation differs from the original in relation to the $c$ axis, which indicates the thickness of the boulder directly exposed to the wave impact. Engel and May (2012) reconsider Nott's equations but use more accurate volume and density measurements and define equations to derive the minimum wave HT or storm wave 


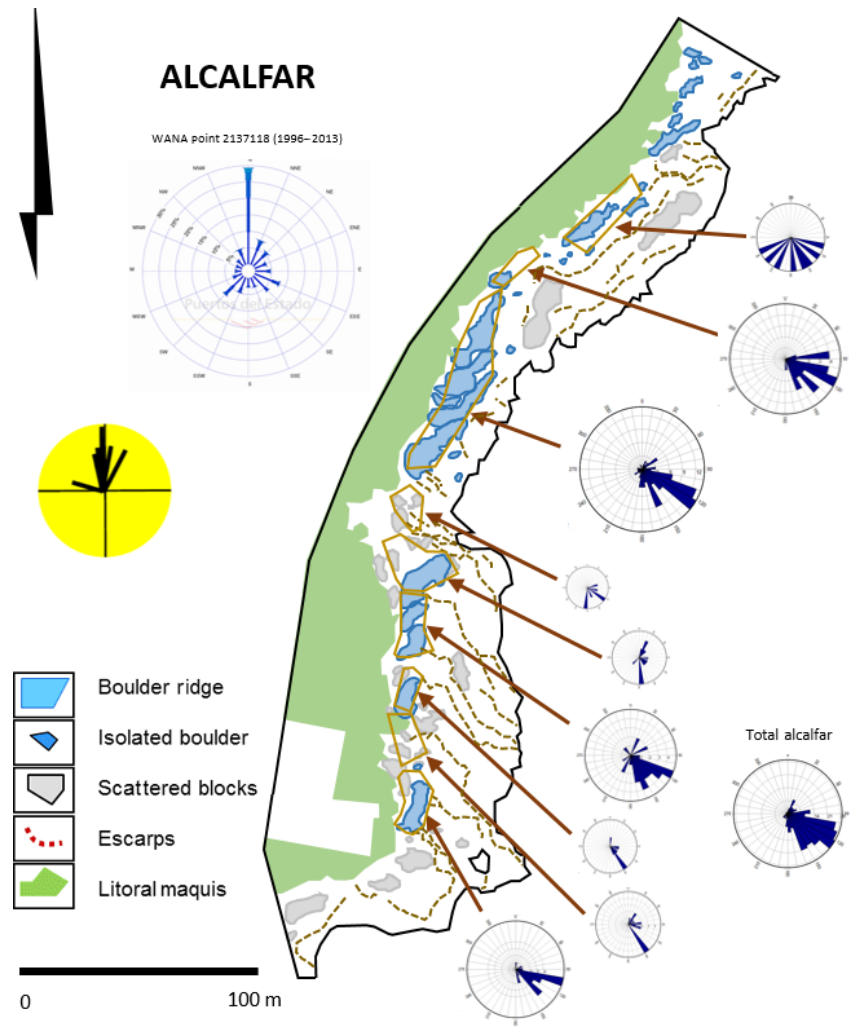

Figure 4. Geomorphology map of the Alcaufar area (SE Minorca) White circles show boulder orientation for each site. Main circle shows mean wave directions recorded at Maó buoy. Yellow circle shows mean extreme wave direction.

height (HS) that is required to dislodge a submerged, subaerial or JBB boulder (Table 2).

The ages of the boulders were determined using two different methods: (a) radiocarbon dating of marine incrusting fauna, and (b) dating surface post-transport features. Most of the boulders show unconformable post-depositional solution pans on the surface, related to karstic dissolutions after the transport of the boulder. Some (Fig. 5b) of these postdepositional solution pans intersect pre-existing ones that developed conformably with stratification. Karstic dissolution rate of these pans was estimated at an average of $0.3 \mathrm{~mm} \mathrm{yr}^{-1}$ (Emery, 1946; Gómez-Pujol et al., 2002). The transport age of 145 boulders from 12 locations was determined using these two methods (Fig. 10).

Other qualitative observations were taken into account: (a) relation of the boulders with their source area and presence of fractures that can promote detachment of the boulders, (b) the presence of incrusting marine fauna indicating the origin of the boulder before its displacement, (c) the presence of pre-detachment and post-detachment solution pans which have been used as date indicators of boulder emplacement, (d) the degree of rounding of the boulders, presence or absence of other types of sediment as well as presence of abrasion surfaces due to boulder quarrying and transport, 
(a)

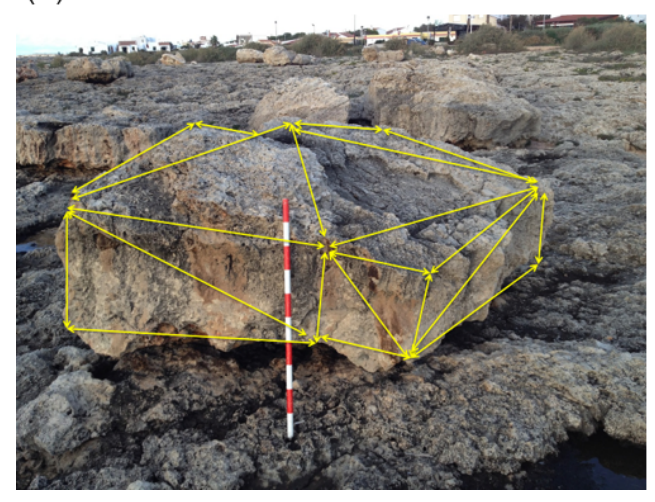

(b)

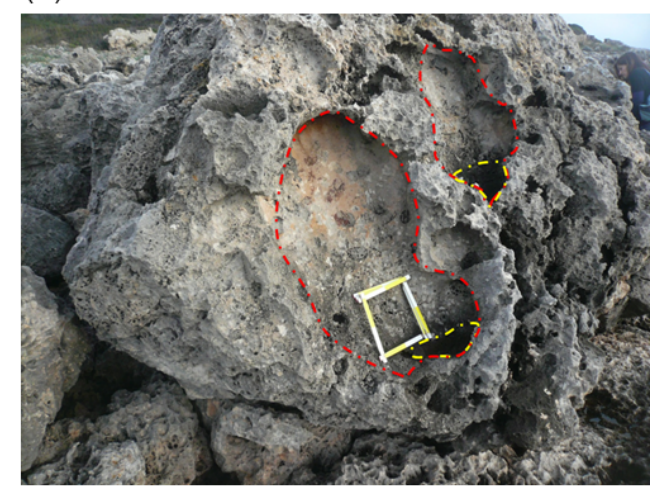

Figure 5. (a) Example of the triangulation of a boulder which obtains the actual volume (sa Caleta, Minorca). (b) Unconformable postdepositional morphologies (yellow) over pre-existing solution pans (red) (son Ganxo, Minorca).

and (e) the presence of flow-outs, which are areas with denudated beds forming channels over the cliff favoring the entry and acceleration of the water flows and leaving a boulder ridge in its front.

\section{Results}

The 24 areas analyzed (Fig. 1) have been grouped into three sectors: SE, W and N. All the boulders were processed, but those with a TF lower than 1000 were excluded from the final analysis. Therefore, results are based on the analysis of 720 boulders.

\subsection{South-eastern sector}

Although 1.766 boulders have been analyzed in eight areas of the SE sector (Figs. 1 and 7), only 274 (16\%) had a $\mathrm{TF}>1000$. These boulders have an average size of $3.1 \mathrm{~m}$ along their longest axis $(a), 2.16 \mathrm{~m}$ along the intermediate axis $(b)$ and $0.9 \mathrm{~m}$ along the shortest axis $(c)$, which usually corresponds to the thickness of the source strata. Mean weight is $11.62 \mathrm{t}$, with a maximum of $229 \mathrm{t}$ on the coastal islet of Illa de l'Aire. Average cliff height is $6.8 \mathrm{~m}$, average height of the boulders is $7.19 \mathrm{~m}$, and average distance from the edge of the cliff is $61.4 \mathrm{~m}$, with extremes of 18.5 and $136 \mathrm{~m}$ respectively. The highest regional storm wave registered (maximum wave height) was $7.5 \mathrm{~m}$ (Cañellas, 2010).

Engel and May (2012) formulations show that the boulders with a TF $>1000$ from this sector require a column of water between $8.8 \mathrm{~m}$ (subaerial) and $14.4 \mathrm{~m}(\mathrm{JBB})$ to explain storm wave run-ups, and between 7.3 and $8.7 \mathrm{~m}$ for the tsunami run-ups.

We calculated that $33 \%$ of the TF $>1000$ boulders are in areas above the maximum stand of the waves registered (7.5 m), and many of them show imbrication patterns. Due to these two reasons, we interpreted these boulder deposits as produced by tsunami events. However, $79 \%$ of all the boul- ders are positioned at a height at which they can be reworked by storm waves.

The boulder setting of this sector can be characterized by the presence of several ridges of imbricate boulders (five of the eight sites show this setting) (Fig. 7), as well as subrounded boulders (5 of 8 ), and isolate groups of imbricate boulders (4 of 8 ). Although the cliff altitude of this sector is quite low (6.8 $\mathrm{m}$, average), and many sites show subrounded blocks (5 of 8), there is no clear relationship between these characters. As an example, some of the lower cliffs do not show any ridges, while some higher cliffs do have ridges.

\subsection{Western sector}

Along the cliffs of the western area (Figs. 1 and 8) 1.043 boulders were measured, and 232 boulders $(22 \%)$ showed a $\mathrm{TF}>1000$. These boulders have an average size of $2.38 \mathrm{~m}$ along the longest axis $(a), 1.86 \mathrm{~m}$ along the intermediate axis $(b)$ and $0.68 \mathrm{~m}$ along the shortest axis $(c)$, which mostly corresponds to the thickness of the source strata. The mean weight of these boulders is $4.6 \mathrm{t}$, with a maximum of $21.9 \mathrm{t}$. The average cliff height is $12 \mathrm{~m}$, and the average boulder height is $16 \mathrm{~m}$ and at a distance of $40 \mathrm{~m}$ from the edge of the cliff, with extremes of 31 and $65 \mathrm{~m}$. The highest regional wave registered was $8.5 \mathrm{~m}$ (Cañellas, 2010).

Formulations from Engel and May (2012) show that the boulders with a TF $>1000$ require a column of water between $13.7 \mathrm{~m}$ (subaerial) and $18.6 \mathrm{~m}$ (JBB) to explain storm wave run-ups, and between 12.4 and $13.6 \mathrm{~m}$ for the tsunami runups. Almost all the TF $>1000$ boulders are positioned above the maximum stand for waves registered along the western coast of Minorca $(8 \mathrm{~m})$. Only $16 \%$ of all the boulders are positioned at a height at which they can be reworked by storm waves. The storm run-up heights for these boulders are out of the reach of storm waves.

The boulder setting of the western sector of Minorca is characterized by higher cliff altitudes and imbricate boulder ridges at half of the sites analyzed (4 of 8). Only two of the 

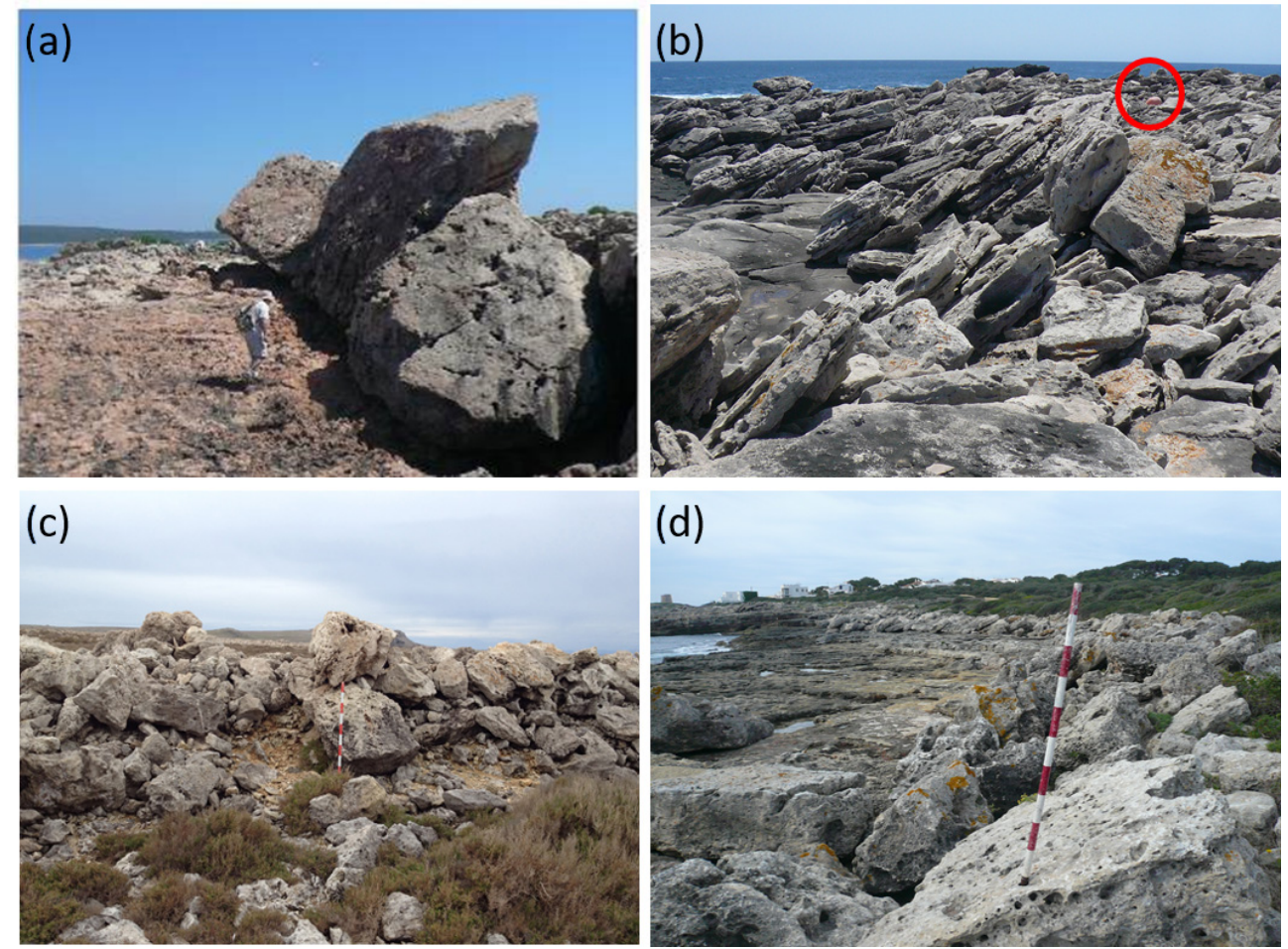

Figure 6. (a) Examples of mega-boulders displaced from the edge of the cliff at Illa de l'Aire, SE Minorca, $15 \mathrm{~m}$ a.s.1. (b) Set of imbricate boulders at Sant Esteve, SE Minorca; buoy in circle is $60 \mathrm{~cm}$ long. (c) Boulder ridge at Punta Nati, W Minorca, $21 \mathrm{~m}$ a.s.1. (d) Ridge of imbricate boulders at Alcaufar, E Minorca, $4.5 \mathrm{~m}$ a.s.l. See Figs. 6 and 8 for location.

Table 3. Comparison for JBB with $\mathrm{TF}>1000$ of calculated storm run-up, tsunami run-up, transport figure and maximum wave height. $H_{\mathrm{S}}$ is average storm wave height from Engel and May (2012), $H_{\mathrm{t}}$ is average tsunami wave height from Engel and May (2012), Alt is average altitude of measured boulders, Rs is run-up needed for storm waves $\left(H_{\mathrm{S}}+\mathrm{Alt}\right)$, Rt is run-up needed for tsunami waves $\left(H_{\mathrm{S}}+\mathrm{Alt}\right)$, TF is transport figure average and $\mathrm{Hm}$ is maximum wave height recorded by Cañelles (2007).

\begin{tabular}{llllllll}
\hline Sector & $H_{\mathrm{S}}$ & $H_{\mathrm{t}}$ & Alt & $\mathrm{Rs}$ & $\mathrm{Rt}$ & $\mathrm{TF}$ & $\mathrm{Hm}$ \\
\hline North & 13.79 & 3.45 & 7.81 & 21.60 & 11.26 & 8,501 & 11.0 \\
West & 6.61 & 1.66 & 11.97 & 18.58 & 13.63 & 2,404 & 8.0 \\
South-east & 7.58 & 1.90 & 6.80 & 14.38 & 8.70 & 2,466 & 7.5 \\
\hline
\end{tabular}

sites show subrounded boulders - the lower sites - and just one has isolated groups of imbricate boulders.

\subsection{Northern sector}

Along the northern coast of Minorca, 338 boulders have been measured (Figs. 1 and 9), and 214 (63\%) showed a $\mathrm{TF}>1000$. The boulders have an average size of $2.56 \mathrm{~m}$ along the longest axis $(a), 1.94 \mathrm{~m}$ along the intermediate axis $(b)$ and $1.3 \mathrm{~m}$ along the shortest axis $(c)$. The mean weight of these boulders is $12.07 \mathrm{t}$, with a maximum of $128.3 \mathrm{t}$ at Illa dels Porros. The average cliff height is $7.81 \mathrm{~m}$, the average boulder height is $11.7 \mathrm{~m}$ and the boulders are at a distance of $66.2 \mathrm{~m}$ from the edge of the cliff, with extremes of 27 and $129 \mathrm{~m}$. The highest regional wave height was calculated at $11 \mathrm{~m}$ (Cañelles, 2010).
Formulations from Engel and May (2012) show that the boulders with TF $>1000$ require a column of water between $9.8 \mathrm{~m}$ (subaerial) and $21.6 \mathrm{~m}$ (JBB) to explain storm wave run-ups, and between 8.3 and $11.3 \mathrm{~m}$ for the tsunami runups. Most of the TF $>1000$ boulders $(74 \%)$ are positioned above the maximum wave height registered along the northern coast of Minorca ( $9 \mathrm{~m}$ ). In addition, $24 \%$ of the boulders are positioned at a height at which they can be reworked by storm waves. The storm run-up heights for boulders of this sector are out of the reach of storm waves.

Few imbricate ridges (just two of the eight sites), only one site with isolated imbricate groups of boulders and a greater presence of subrounded blocks (6 of 8 ) characterize the setting of the northern boulders. 

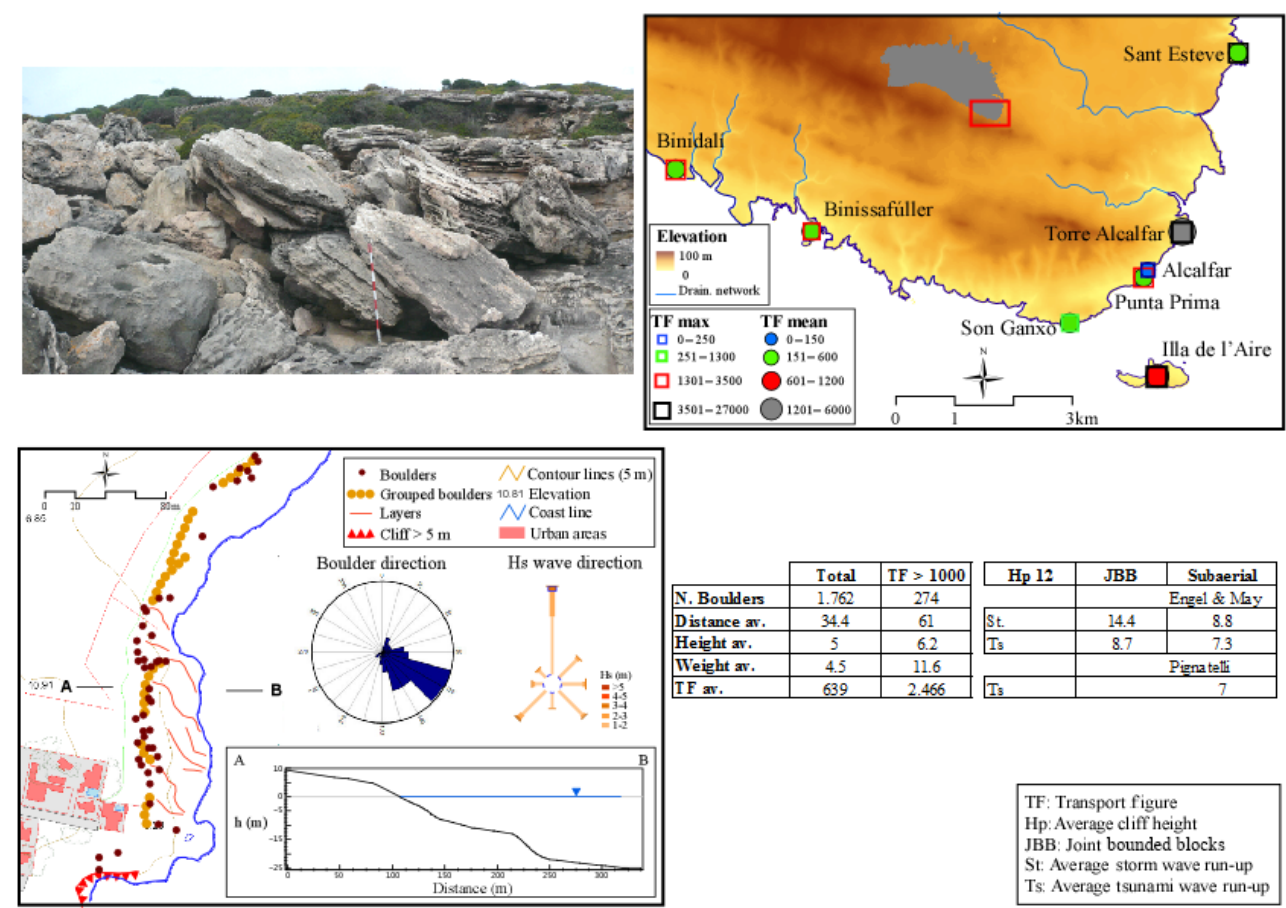

Figure 7. Location and main characteristics of SE Minorca boulders. Picture corresponds to an imbricate ridge of boulders in Sant Esteve. Geomorphological sketch shows boulder distribution at Alcaufar.

\subsection{Biggest boulders}

The results for each area indicate the average size and weight for all the boulders with a TF $>1000$, but we will consider some of our findings on the largest boulders of each area. The largest boulders of the SE area of Minorca are located on Illa de l'Aire (Fig. 7), just $960 \mathrm{~m}$ off the SE coastal tip of Minorca. The largest boulders of this area weigh 228, 154 and $114 \mathrm{t}$. The Engel and May (2012) equations provide storm run-up estimations of 32, 23 and $22 \mathrm{~m}$ respectively, while for a tsunami run-up they required 12,9 and $9 \mathrm{~m}$.

The largest boulders on the western area of Minorca weigh $21.9,18.2$ and $16.8 \mathrm{t}$, but they are located higher up and more inland than those of the SE coast. The results of the Engel and May (2012) equations of this area show storm run-ups of 20.2, 16.4 and $16.5 \mathrm{~m}$ and tsunami run-ups of $9.9,10.5$ and $10.5 \mathrm{~m}$.

The largest boulders on the northern coast weigh 128.3, 56.5 and $53.7 \mathrm{t}$. They are found on the small islet of Illa des Porros (Fig. 9), just $426 \mathrm{~m}$ off the northern tip of Minorca (Fig. 9). According to the equations from Engel and May (2012), storm run-ups of 46.3, 45.4 and $37.7 \mathrm{~m}$ are required to transport these boulders, and heights of 19.8, 22.6 and $16.6 \mathrm{~m}$ are required for a tsunami run-up.

\subsection{Dating age of the deposits}

Five of the analyzed boulders show marine fauna, indicating that they have been dislodged from the submerged area and deposited above the cliff. Two of these boulders have been sampled for ${ }^{14} \mathrm{C}$ dating: a boulder from Son Ganxo (SE Minorca, Fig. 7) is a fragment of shoreline notch (wave-cut notch) located $2.5 \mathrm{~m}$ a.s.1., at a distance of $18.4 \mathrm{~m}$ from the cliff edge, with a weight of $4.75 \mathrm{t}$. Radiocarbon dating determined an age younger than $1964 \mathrm{AD}$ (RICH21441: $106.96 \pm 0.39 \mathrm{BP}$, calibrated after $1965 \mathrm{AD}$ with the marine curve). Another boulder in Sant Esteve (SE Minorca, Fig. 7) is situated about $19 \mathrm{~m}$ from the waterfront and $1 \mathrm{~m}$ a.s.l., with a weight of $43.15 \mathrm{t}$, and ${ }^{14} \mathrm{C}$ dating determined an age younger than $1720 \mathrm{AD}$ (RICH-21442: $518 \pm 31 \mathrm{BP}$, cal AD 1720-1950 for $95.4 \%$ and cal AD 1804-1910 for $68.3 \%)$.

Some of the boulders in the spray areas show postdepositional dissolution pans (Fig. 5b). Although dissolution rate for these pans is not uniform (it increases near the cliff edge), we have considered an average of $0.3 \mathrm{~mm} \mathrm{yr}^{-1}$ (Emery, 1946; Gómez-Pujol et al, 2002). This rate has been used to date the age of 145 pans found on the surface of the boulders (Fig. 10).

Radiocarbon dating and estimating dates using dissolution ratios provided a range of ages for 12 locations between 1574 and $1813 \mathrm{AD}$, although 8 of the 12 dates are around the year 1790 AD (Fig. 10).

These results place the processes that lead to the deposition of blocks within a few hundred years, discarding geologically older events. In all likelihood, there were previous 


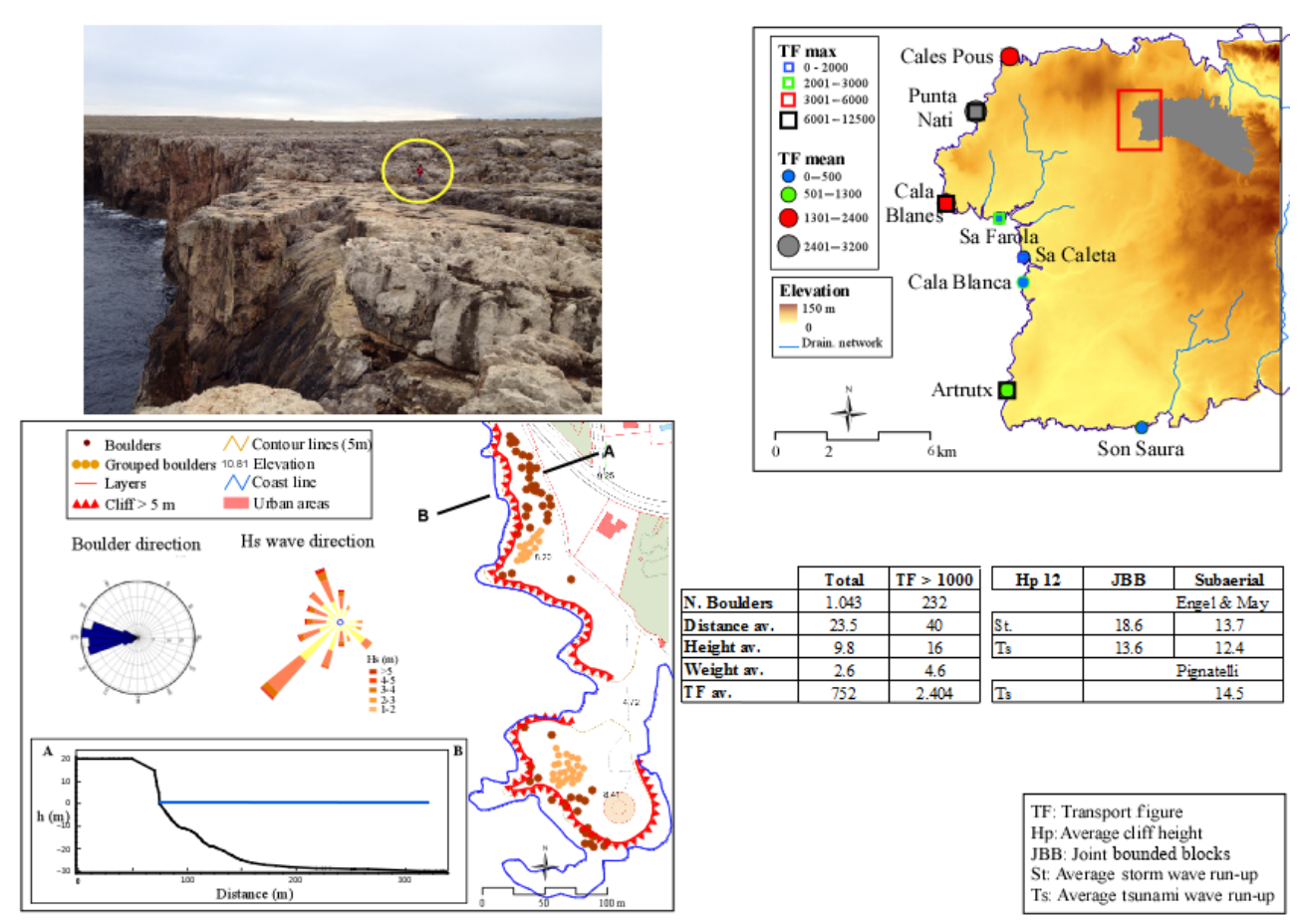

Figure 8. Locations and main characteristics of W Minorca boulders. Picture corresponds to isolated boulders from Punta Nati (31 m a.s.1.). Geomorphological sketch shows boulder distribution at Sa Caleta.
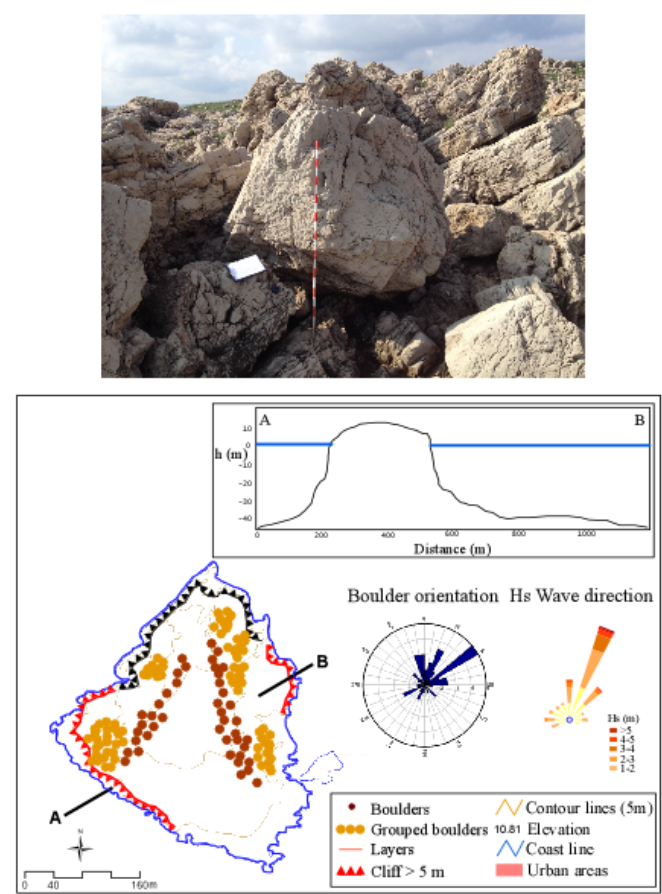
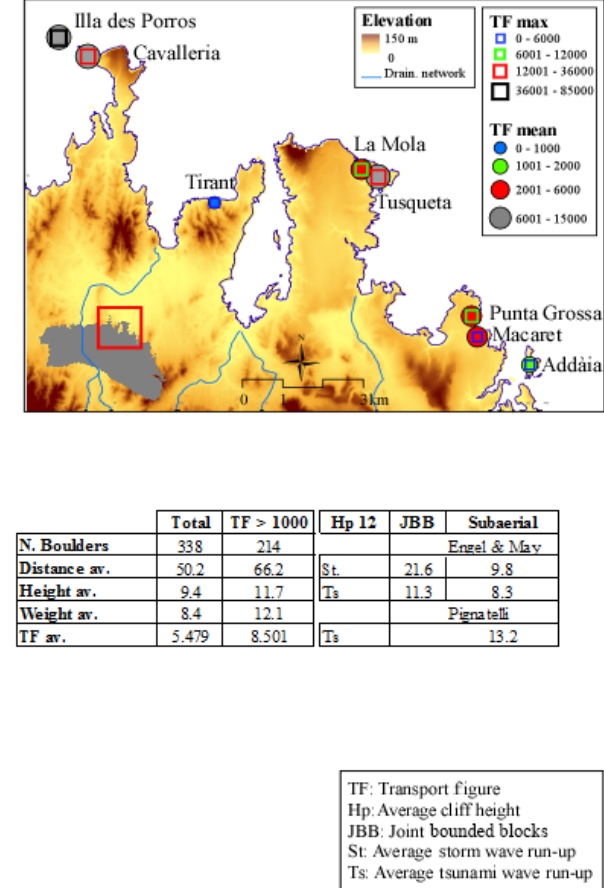

Figure 9. Location and main characteristics of N Minorca boulders. Picture corresponds to caballería boulders. Geomorphological sketch shows boulder distribution at Illot d'Addaia. 


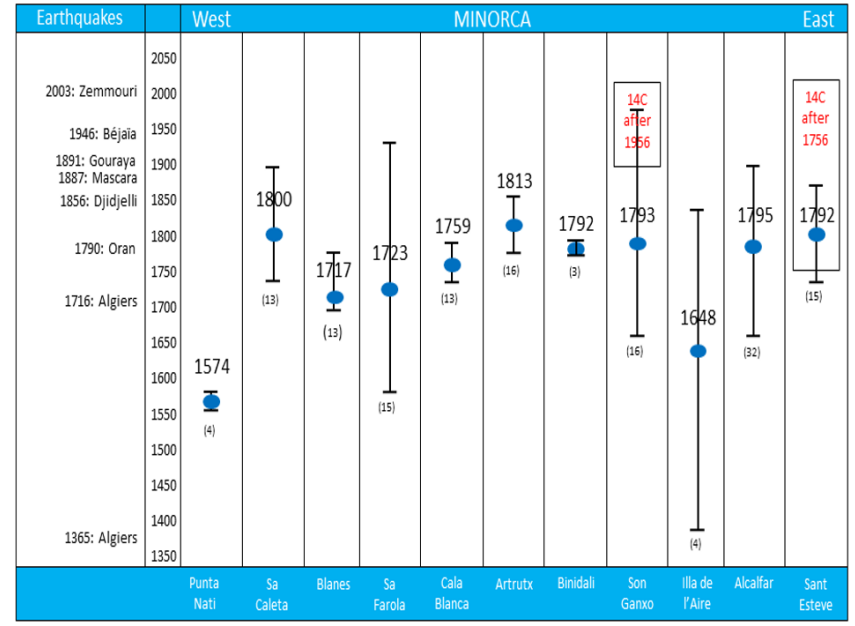

Figure 10. Chronology of the post-depositional dissolution pans found on the surface of southern Minorca boulders: the ages, in years $\mathrm{AD}$, correspond to the post depositional dissolution pans measured on the boulders of the sampled localities. The blue dots indicate the average age of each locality. The bar indicates the range of dispersion of calculated ages, and the numbers in parentheses show the number of measured pans in each area. The left column displays the earthquakes that have occurred with intensity $>X$ in the northern Algerian coast since 1365. Rectangles indicate the age obtained through ${ }^{14} \mathrm{C}$.

events that either were obscured by the youngest and most intense events or have not yet been possible to identify.

\section{Discussion}

In interpreting the cause of extreme wave events, there are two feasible hypotheses, namely tsunami waves or storm waves. The former are long period waves (up to $10^{2} \mathrm{~min}$ ) of long wavelength $(>100 \mathrm{~km})$; the latter are characterized by much shorter periods (max. $25 \mathrm{~s}$ ) and length $\left(10^{2} \mathrm{~m}\right)$. Because of their long wavelengths, tsunami waves possess a minimum factor of 4 times greater power in relation to their height than storm waves (Mottershead et al., 2014). The impact of a tsunami on a cliff has to be compared to that of a flood, since the mass of water, overflowing the edge of the cliff, produces a flow inland equivalent to a massive flood. The action of the storm waves, as well as being more local and more dependant on the conditions predicted by the cliff (fractures, abrasion caves, etc.), depends a lot on the bathymetry prior to the cliff, which determines the slope of the wave and the distance of its break. In the Balearic Islands, the comparison between the run-ups of tsunamis and storm waves must also consider their proximity to tsunamigenic sources and the reduced fetch available for the storm waves, especially those that come from the south. This greater power enables tsunamis to achieve both detachment of significantly larger bedrock clasts and also much greater run-up heights and run-in distances.

Small recent tsunamis have affected the island of Minorca as stated by local newspapers (Diario de Menorca, 2003, 22 and 23 May). The tsunamigenic source is the Algerian coast, which, according to the historical and instrumental seismicity, is exposed to relevant seismic hazards and risks ( $\mathrm{Pa}-$ padopoulos, 2009). The last tsunami that affected Minorca island was generated by the Zemmouri (Algeria) earthquake that took place on 21 May 2003, with a magnitude of $6.9 M_{\mathrm{w}}$. This earthquake was generated by a reverse fault, leading to a significant deformation of the seabed and creating a tsunami that was observed in Algeria and Spain, and even reached the coasts of France and Italy. This event included $3 \mathrm{~m}$ high waves in Ibiza, the highest tsunami waves recorded in recent years in the Balearic Islands, which damaged some of the harbor facilities on Minorca, Majorca and Ibiza. A fragment of the chronicle about the tsunami in Diario de Menorca (22 May 2003) stated: "In the case of the Port of Maó (the capital city of Minorca), the movement of the waters was spectacular: no sooner had it disappeared from the shore, leaving the bottom of the harbor uncovered, then it returned, flooding the seafront and even the road. The same situation was experienced simultaneously in Cales Fonts, Cala Alcaufar and Cala Sant Esteve (three inlets in the E coast of Minorca), where some hammocks were $300 \mathrm{~m}$ from the beach, along with dead fish" (see Fig. 7 for location). Unfortunately, we did not study the effects of the tsunami on the boulders at that time. Tsunami simulations of this event (Fig. 3) were performed by several authors (Hébert and Alasset, 2003; Alasset et al., 2006; Roger and Hébert, 2008).

Thus, there is currently seismic activity at the bottom of the Algerian basin that gives rise to tsunamis affecting the coast of Minorca. In the recent past, in the last 500 years, there have been tsunamis affecting the Balearic Islands (Table 1). There are also historical tsunami records reporting a flood event with a run-in of to $2 \mathrm{~km}$ inland in Santanyí (location on Fig. 2), on the eastern coast of Majorca in 1756 (Fontseré, 1918). Numerical models of tsunami simulation from submarine earthquakes at the northern African coast (i.e. Álvarez-Gómez et al., 2011; Roger and Hébert, 2008) show that the south-eastern and western areas of Minorca would be the most affected by the tsunami impacts. The fetch length for the southern coast of Minorca is relatively low: $300 \mathrm{~km}$ in the $\mathrm{S}$ direction and $500 \mathrm{~km}$ in the easterly direction. Thus, in the last 50 years the maximum extremal wave height detected in an offshore buoy was $11 \mathrm{~m}$ high at the 2001 medicane (Jansà, 2013).

According to Papadopoulos (2009), the major tsunamigenic source in the western Mediterranean is located north of Algeria (Fig. 2), although the Alborán region has to be taken into account too. In other areas as the Liguro-Provençal basin and the Valencia trough (Fig. 2), the seismicity is too low for it to be classified as a tsunamigenic area. The seismicity of the northern region of Algeria is dominated by thrust focal 
mechanisms to the west and central part of this area and by strike-slip faults to the east (e.g., Bezzegoud et al., 2014). The Alboran region is dominated by strike-slip and extensional focal mechanisms where the largest magnitudes are usually low to moderate (Vanucci et al., 2004).

If we focus on northern Algeria, since 1716 there have been seven seismic events (Fig. 10) with intensities greater than $X$ recorded by Ayadi and Bezzegoud (2014) that are capable of causing a tsunami that, according to the numerical models, will directly hit the coast of Minorca (especially the southern one). According to the same authors, only one seismic event of high intensity is recorded prior to 1716: Algiers, 3 January 1365. Thus, in the period 1716-2017 seven highmagnitude events have been recorded, whereas between 1365 and 1715 only one high-magnitude event has been recorded. This is probably due to the lack of information as we go back in time and the frequency of the first period is probably hidden in some way.

The geographical distribution of boulder sites (Figs. 1 and 3 ) in the Balearic Islands gives clear indications of their tsunamitic origins. Boulder sites in Majorca are distributed along the eastern and southern coasts and the same is found in Ibiza. Only in Minorca did we find boulder sites on the northern coast, despite most of the boulder settings being located on the southern coast of the island. In Fig. 3 we show a perfect correspondence between the expected locations where a northern-Africa-generated tsunami should hit the Balearic Islands (from numerical model simulation) and the sites where boulder accumulations are. Storm waves have larger fetch in the northern coast of the Balearic Islands, but almost no large boulders have been found on the western and northern coasts of Majorca, nor on the northern coast of Ibiza.

Although we are aware that hydrodynamic equations need to be reviewed (Cox et al., 2018) and they are not a definitive approach for discerning tsunami boulders from storm boulders, we used the Engel and May (2012), and Nott (2003) and Pignatelli et al. (2009) equations. The Engel and May equation calculates the wave height needed to transport boulders located at sea level. The boulder heights are not contemplated in this equation. In Table 3 we present the average results for joint-bounded boulders (JBB) of the three sectors studied. $H_{\mathrm{S}}$ (storm wave height needed to move a boulder at sea level) is, in the three sectors, approximately 4 times $H_{\mathrm{t}}$ (tsunami wave height needed to move a boulder at sea level). Because $H_{\mathrm{s}}$ is approximately equal (or higher) to $\mathrm{Hm}$ (the maximum wave height recorded), storms on Minorca cannot move any boulder with transport figure $>1000$, not even the ones located at sea level. This point agrees with our observations in the field that the biggest storm wave ever recorded in Minorca moved none of the boulders marked by us in advance. However, tsunami waves heights of less than $4 \mathrm{~m}$ at the northern sector or less than $2 \mathrm{~m}$ in the western and southern sectors can move boulders with TF $>1000$ at sea level. The run-up values given in the text are the sum of $H_{\mathrm{s}}$ and Alt (the average altitude of boulders) for storm run-up (Rs) and the sum of $H_{\mathrm{t}}$ and Alt for tsunami run-up (Rt). Along the SE sector of the Minorca coastline, for joint-bounded boulders, storm run-ups of $14.4 \mathrm{~m}$ are required to explain the positions of the boulders, while only $8.7 \mathrm{~m}$ tsunami run-ups can explain the same positions. Results along the higher cliffs of the western coastline require tsunamis run-ups of $13.6 \mathrm{~m}$ and/or storm run-ups of $18.6 \mathrm{~m}$. The calculations along the northern coast require storm run-ups of more than $21 \mathrm{~m}$, which are not plausible, while the height of a tsunami run-up required to position the boulders is $11.3 \mathrm{~m}$.

According to the setting of the boulders and the results of the hydrodynamic equations, it seems clear than large boulders cannot be transported by a single storm event, nor by a series of storms. However, hydrodynamic equations require run-ups of the tsunami wave that multiply the heights that models forecast for tsunami waves in the open sea between 2 and 10 times. First of all, the run-up of tsunamis on vertical cliffs is several times higher than that occurring in low coastal areas (Bryan, 2001). Run-up is also enhanced due to several factors (Lekkas et al., 2011): (1) the distance from the tsunami generation area (of only $300 \mathrm{~km}$ in our case), (2) the narrowness of the continental shelf (as in Minorca), (3) the fact than the tsunami propagation vector is almost perpendicular to the main shoreline direction, and (4) by land morphology, characterized by vertical cliffs with entrances (inlets). For these reasons, run-ups heights on Minorca should be several times higher than tsunami wave heights. However, as they shoal, wave heights increase run-up heights to a lesser extent and thus, it is impossible to reach the run-up values obtained from the hydrodynamic equations.

Recent examples in the Balearic Islands confirm the last statement: the tsunami of 2003 had an offshore wave height of $30-40 \mathrm{~cm}$ (according to simulations) and reaches the western part of Ibiza with a run-up of $3 \mathrm{~m}$, which means a multiplying factor of $\times 10$. In November 2017, a severe storm caused waves of up to $11 \mathrm{~m}$ offshore north of Minorca. These waves, after breaking, decreased their height when arriving on the coast of Minorca. A field survey, taken days after the storm, reveal that none of the boulders marked in advance moved (even those located at only $1 \mathrm{~m}$ a.s.1.), nor did new blocks appear.

Regarding the dating of the boulders, although only two blocks with embedded marine fauna (and located only $1 \mathrm{~m}$ above the sea level) have been radiocarbon dated, dates serve as a reference to the second dating method used. Our ${ }^{14} \mathrm{C}$ results show that in one case a block was moved after $1856 \mathrm{AD}$, and in the other case it was transported after 1964.

The second dating method is based on an average dissolution rate of dissolution pans. This requires identifying postdepositional dissolution pans, that is, those that have been formed after the movement of the boulders. They can be formed on the same boulder once transported or on the denudation surface that results from the quarry of the boulder. A margin of error can be established based on the variabil- 
ity of the dissolution rate, which is not very high because the boulders are located away from the cliff edge, where the dissolution rate is more variable. However, in no way do the resulting values (age values) match with marine levels that are different from the current one. Other similar boulders dated by Kelletat et al. (2005) on the neighboring island of Majorca have ages between 565 and $1508 \mathrm{AD}$.

Estimations using dissolution rates of surface pans are consistent with the two macro-fauna radiocarbon ${ }^{14} \mathrm{C}$ dates. Historical records of earthquakes and associated tsunamis (Fontseré, 1918; Martinez-Solares, 2001; Silva and Rodríguez Pascua, 2014) are also consistent with our chronology (Fig. 10). Among the historical records of huge wave phenomena that have affected the Balearic Islands, there are also some episodes that can be attributed to tsunamis. In 1856, the chronicles written by Fontseré (1918) record an extraordinary sea rise in the Port of Maó (Minorca) that destroys several moorings. In 1918, a new "seismic wave" floods the Port of Maó, following an earthquake off the Algerian coast (Fontseré, 1918). The data from the National Geographic Institute of Spain (Martinez-Solares, 2001 and Silva and Rodríguez Pascua, 2014) record the presence of a tsunami in 1756 that flooded more than $2.4 \mathrm{~km}$ inland in Santanyí (location on Fig. 2) on the southern coast of Majorca (Fontseré, 1918). A run-up up to $45 \mathrm{~m}$ must be deduced from that description. In all likelihood, some tsunamis have not been reflected in the historical chronicles because in the recent past (18th, 19th and early 20th centuries) the coastal part of the Balearic Islands was uninhabited. Only the tsunamis that historically affected the towns near the coast were recorded.

Finally, settings of the boulders depend on local physiography and the characteristics of the flow that transported them. Most of the imbricate ridges are found along the SE sector, with lower cliffs and a bigger impact from potential tsunamis. Up to $62 \%$ of the boulders along the SE coastline are subrounded, indicating some reworking by storm waves. Boulders along the western sites are positioned higher, and only $25 \%$ are subrounded, overlapping with the presence of flow-out morphologies. Most of the boulders in this sector have been detached and transported by tsunami flows, but storm waves have moved some boulders several centimeters, reworking them locally. The position of the boulders along the northern coast sector shows evidence of both tsunami and storm wave flows: $75 \%$ of the sites have subrounded blocks and just $25 \%$ of the sites have imbricate ridges. The weight, distance inland and height of some boulders cannot be explained by storm waves. The tsunamis hitting the northern coast of Minorca could be caused by a refraction of a tsunami wave originating from the northern African coast but we do not exclude submarine landslides occurring off the Catalan platform or at the Liguro-Provençal basin platform (Fig. 3).

\section{Conclusions}

More than 3000 large boulders have been analyzed on the coastal platforms of Minorca, 720 of which (the ones with larger transport figure values) have been selected for this study. Weight, height above sea level and distance from the edge of the cliff indicate that they have been dislodged and positioned by the action of tsunami waves, although some of these boulders have also been reworked by storm waves.

Boulder sites in the Balearic Islands are mainly located in the southern and eastern parts of the islands. This fact demonstrates that they have been transported by tsunamis and not by storms: whereas the prevailing and strongest wind comes from the north, the main tsunamigenic area is the Algerian coast, located S-SE of the Balearic Islands.

Tsunamis generated off the Algerian coast are quite well known. What was little known is the potential impact of these waves on the coastline of the Balearic Islands, including Minorca. Tsunami simulation models have confirmed the high probability of tsunami wave impact along the coast of the Balearic Islands. The historical chronicles of tsunami events hitting the islands have supported these models. The last 2003 tsunami episode caused a large amount of damage to some harbors of the Balearic Islands.

Despite the location of the boulders being very important, further information obtained from boulder orientations and the presence of imbricated ridges and/or isolated groups of imbricated boulders is evidence of a continuous flow which can only originate from a tsunami. Distance from local escarpments can exclude any of the analyzed boulders that originated from a rockfall.

Hydrodynamic equations applied to these boulders give wave run-up values that are very far from the reach of the waves recorded in the last 50 years, a clear indication that a tsunami wave was the cause of their dislodgement, transport and setting. Weights up to $228 \mathrm{t}$ (Illa de l'Aire, Fig. 7), altitudes reaching $31 \mathrm{~m}$ (Punta Nati, Fig. 8) above sea level, and distances from the cliff edge of up to $136 \mathrm{~m}$ (Illa de l'Aire) confirm the results obtained in our calculations. Historical data on storm waves, or even medicane $(11 \mathrm{~m})$ events, cannot explain the size and positioning of the boulders.

Dating by ${ }^{14} \mathrm{C}$ and ages obtained from pan dissolution rates establish an age range for tsunami emplacement of the studied boulders between the 17th and 19th centuries. During this period, seven earthquakes with intensities larger than $X$ have been documented along the northern Algerian coast and 11 historical tsunami phenomena have been described by historical records in the Balearic Islands.

Data availability. Most of the data come from Roig-Munar (2016). 
Author contributions. Most of the field data were obtained by FXRM in his phD thesis. Processing, mapping and GIS was done by JAMP. AR and JMV were phD directors. All authors have agreed on the final version and have made substantial contributions to conception and design, acquisition of data, or analysis and interpretation of data, drafting the article or critically revising the intellectual content.

Competing interests. The authors declare that they have no conflict of interest.

Acknowledgements. This study was supported by the projects CGL2013-48441-P, the CGL2016-79246-P (AEI/FEDER, UE), the CHARMA project (MINECO, ref. CGL2013-40828-R), the PROMONTEC project (MINEICO, ref. 444CGL2017-84720-R) and the CSO20015-64468-P (MINECO/FEDER) project.

Edited by: Mauricio Gonzalez

Reviewed by: two anonymous referees

\section{References}

Alasset, J. P., Hébert, H., Maouche, S., Calbini, V., and Meghraoui, M.: The tsunami induced by the 2003 Zemmouri earthquake $\left(M_{\mathrm{W}}\right.$ p 6.9 Algeria): modelling and results, Geophys. J. Int., 166, 213 226, 2006

Álvarez-Gómez, J. A., Aniel-Quiroga, 1., González, M., and Otero, L.: Tsunami hazard at the Western Mediterranean Spanish coast from seismic sources, Nat. Hazards Earth Syst. Sci., 11, 227240, https://doi.org/10.5194/nhess-11-227-2011, 2011.

Ayadi, A. and Bezzegoud, M.: Seismicity of Algeria from 1365 to 2013: Maximum Observed Intensity Map (MOI2014), Seismol. Res. Lett., 86, 236-244, 2015.

Barbano, M. S., Pirrotta, C., and Gerardi, F.: Large boulders along the south-eastern Ionian coast of Sicily: Storm or tsunami deposits?, Mar. Geol., 275, 140-154, 2010.

Barbano, M. S., Gerardi, F., and Pirrotta, C.: Differentiation between boulders deposited by tsunamis and storm waves along the south-eastern Ionian coast of Sicily (Italy), B. Geofis. Teor. Appl., 52, 707-728, 2011.

Bartel, P. and Kelletat, D.: Erster Nachweis holozäner Tsunamis im Westlichen Mittelmeergebiet (Majorca, Spanien) mit einem Vergleich von Tsunamiund Sturmwellenwirkung auf Festgesteinsküsten, Ber. Forsch. Technol.-Center, Kiel, Büsum, 28, 93-107, 2003.

Bertotti, L. and Cavaleri, L.: Analysis of the Voyager storm, Ocean Eng., 35, 1-5, 2008.

Bezzegoud, M., Adam, C., Buforn, E., Borges, J. F., and Caldeira, J. F.: Seismicity along the Azores-Gibraltar region and global plate kinematics, J. Seismol., 18, 205-220, 2014.

Bryan, E.: Tsunami: The Underrated Hazard, Cambridge University Press, 350 pp., 2001.

Cañellas, B.: Long-term extreme wave height events in the Balearic Sea: characterization, variability and prediction, $\mathrm{PhD}$ Thesis, Universitat de les Illes Balears, 71 pp., 2010.
Cox, R., Jahn, K. L., Watkins, O. G., and Cox, P.: Extraordinary boulder transport by storm waves (west of Ireland, winter 20132014) and criteria for analysing coastal boulder deposits, EarthSci. Rev., 177, 623-636, 2018.

Emery, K. O.: Marine solution basins, J. Geol., 54, 209-228, 1946.

Engel, M. and May, S. M.: Bonaire's boulder fields revisited: Evidence for Holocene tsunami impact on the Lee-ward Antilles, Quaternary Sci. Rev., 54, 126-141, 2012.

Etienne, S. and Paris, R.: Boulder accumulation related to storms on the south coast of the Reykjanes Peninsula (Iceland), Geomorphology, 114, 55-70, 2010.

Fontseré, E.: Notas sueltas de sismología Balear. Publicaciones de la Sección de Ciencias Naturales, Facultad de Ciencias de la Universidad de Barcelona, 5-12, 1918.

Genovés, A., Campins, J., and Jansà, A.: Intense storms in the Mediterranean: a first description from the ERA-40 perspective, Adv. Geosci., 7, 163-168, https://doi.org/10.5194/adgeo-7-1632006, 2006.

Gómez-Pujol, L. Balaguer, P., and Fornos, J. J.: Meteorización del patrimonio histórico en ambientes costeros marinos: el caso de la Torre d'en Beu (Santanyí, Majorca), in: Estudios recientes (2000-2002) en Geomorfología, edited by: Serrano, E., García de Celis, A., Guerra, J. C., Morales, C. G., and Ortega, M. T., PUV, Valladolid, Comunicaciones, 403-413, 2002.

Hall, A. M.: Storm wave currents, boulder movement and shore platform development: a case study from East Lothian, Scotland, Mar. Geol., 283, 98-105, 2011.

Hansom, J. D. and Hall, A. M.: Magnitude and frequency of extratropical North Atlantic cyclones: a chronology from cliff-top storm deposits, Quatern. Int., 195, 42-52, 2009.

Hérbert, H. and Alasset, P. J.: The Tsunami Triggered by the 21 May 2003 Algiers Earthquake, EMSC Newsletter, Centre Sismologique Euro-Méditerranéen, 20, 10-12, 2003.

Homar, V., Jansà, A., Campins, J., and Ramis, C.: Towards a climatology of sensitivities of Mediterranean high impact weather - first approach, Adv. Geosci., 7, 259-267, https://doi.org/10.5194/adgeo-7-259-2006, 2006.

Jansà, A.: Los ciclones mediterráneos y sus impactos en España, in: García-Legaz, C. I. and Valero, F., Fenómenos meteorológicos adversos en España, AMV Ediciones, Madrid, 1, 17-33, 2013.

Kelletat, D., Whelan, F., Bartel, P., and Scheffers, A.: New Tsunami evidences in Southern Spain Cabo de Trafalgar and Majorca Island, in: Geomorfologia Litoral I Quarternari, edited by: Sanjaume, E. and Matheu, J. F., Homenatge al professor Vincenç M Rosselló i Verger, Universitat de València, Spain, 215-222, 2005.

Lekkas, E., Andreadakis, E., Kostaki, I., and Kapourani, E.: Critical Factors for Run-up and Impact of the Tohoku Earthquake Tsunami, Int. J. Geosci., 2, 310-317, 2011.

Lionello, P. and Sanna, A.: Mediterranean wave climate variability and its links with NAO and Indian Monsoon, Clim. Dynam., 25, 611-623, 2006.

Maouche, S., Morhange, C., and Meghraoui, M.: Large boulder accumulation on the Algerian coast evidence tsunami events in the western Mediterranean, Mar. Geol., 262, 96-104, 2009.

Martinez-Solares, J. M.: Los efectos en España del terremoto de Lisboa (1 denoviembre de 1755), Dirección General del Instituto Geográfico Nacional, 756 pp., 2001.

Mastronuzzi, G. and Pignatelli, C.: The boulder berm of Punta Saguerra (Taranto, Italy): a morphological imprint of the Rossano 
Calabro tsunami of April 24, 1836?, Earth Planets Space, 64, 973-989, 2012.

Mastronuzzi, G., Pignatelli, C., Sanso, P., and Selleri, G.: Boulder accumulations produced by the 20th February 1743 tsunami along the coast of South Eastern Salento (Apulia region, Italy), Mar. Geol., 242, 191-205, 2007.

Mottershead, D., Bray, M., Soar, P., and Farres, P. J.: Extreme wave events in the central Mediterranean: geomorphic evidence of tsunami on the Maltese Islands, Z. Geomorphol., 58, 385-411, 2014.

Nott, J.: Waves, coastal boulder deposits and the importance of the pretransport setting, Earth Planet. Sc. Lett., 210, 269-276, 2003.

Papadopoulos, G. A.: The development of the National Tsunami Warning System of Greece, EMSC Newsletter, 23, 20-21, 2009.

Pignatelli, C., Sanso, P., and Mastronuzzi, G.: Evaluation of tsunami flooding using geomorphologic evidence, Mar. Geol., 260, 6-18, 2009.

Roig-Munar, F. X.: Blocs de tempesta i tsunami a les costes rocoses de les Illes Balears, Anàlisi geomorfològica i morfomètrica, $\mathrm{PhD}$ Thesis, unpublished, Departament de Geodinàmica i Geofísica, Universitat de Barcelona, http://hdl.handle.net/2445/103318 (last access: 28 June 2018), 410 pp., 2016.

Roger, J. and Hébert, H.: The 1856 Djijelli (Algeria) earthquake and tsunami: source parameters and implications for tsunami hazard in the Balearic Islands, Nat. Hazards Earth Syst. Sci., 8, 721-731, https://doi.org/10.5194/nhess-8-721-2008, 2008.

Scheffers, A. and Kelletat, D.: Sedimentologic and geomorphic tsunami imprints worldwide - a review, Earth-Sci. Rev., 63, 8392, 2003.

Scheffers, A. and Kinis, S.: Stable imbrication and delicate/unstable settings in coastal boulder deposits: Indicators for tsunami dislocation?, Quatern. Intern., 332, 73-84, 2014.
Scicchitano, G., Monaco, C., and Tortorici, L.: Large Boulder deposits by tsunami along the Ionian coast of south-eastern Sicily (Italy), Mar. Geol., 238, 75-91, 2007.

Scicchitano, G., Pignatelli, C., Spampinato, C. R., Piscitelli, A., Milella, M., Monaco, C., and Mastronuzzi, G.: Terrestrial Laser Scanner techniques in the assessment of tsunami impact on the Maddalena peninsula (south-eastern Sicily, Italy), Earth Planets Space, 64, 889-903, 2012.

Shah-Hosseini, M., Morhange, C., De Marco, A., Wante, J., Anthony, E. J., Sabatier, F., Mastronuzzi, G., Pignatelli, C., and Piscitelli, A.: Coastal boulders in Martigues, French Mediterranean: evidence for extreme storm waves during the Little Ice Age, Z. Geomorphol., 57, 181-199, 2013.

Silva, P. and Rodríguez Pascua, J.: Catálogo de los efectos geológicos de los terromotos en España, Instituto geológico Minero de España, 358 pp., 2014.

Soloviev, S. L.: Tsunamigenic zones in the Mediterranean Sea, Nat. Hazards, 3, 183-202, 1990.

Sotillo, M., Ratsimandresy, A., Carretero, J., Bentamy, A., Valero, F., and González-Rouco, F.: A high-resolution 44- year atmospheric hindcast for the mediterranean basin: contribution to the regional improvement of global reanalysis, Clim. Dynam., 25, 219-236, 2005.

Vanucci, G., Pondrelli, S., Argnani, A., Morelli, A., Gasperini, P., and Boschi, E.: An atlas of Mediterranean seismicity, Ann. Geophys., Supplement to vol. 47, 247-306, 2004.

Vela, J., Pérez, B., González, M., Otero, L., Olabarrieta, M., Canals, M., and Casamor, J. L.: Tsunami resonance in Palma bay and harbor, Majorca Island, as induced by the 2003 Western Mediterranean earthquake, J. Geol., 122, 165-182, 2014. 